\title{
RINDAL AND ELCHINOV: A(N) (IMPENDING) REVOLUTION IN EU LAW ON PATIENT MOBILITY?
}

\begin{abstract}
Tomislav Sokol*
Summary: This paper critically analyses EU law on patient mobility, which has developed in the last decade. It covers the European Court of Justice case law applying internal market rules to social security coverage of foreign health treatment, its relationship with the $E U$ rules on the co-ordination of social security systems, and the recent attempts at codifying the case law. The most recent EFTA Court judgment in the Rindal case, and its potential effects on EU law if the Court of Justice adopts the same reasoning in the pending Elchinov case, are investigated.

The aim of this paper is to demonstrate the implications of EU law on patient mobility on national social security systems, namely their autonomy to define the scope of their coverage of health care treatment, and the consequences, within the framework of EU law, of applying certain legal techniques to define their social packages. Special emphasis is put on the new EU Member States and Croatia. It is argued that these states are in a particularly delicate position in relation to EU law in terms of maintaining the financial stability and the social (in terms of solidarity) character of their social security systems.

The paper proposes certain solutions to accomplish a twofold objective: improving legal certainty at the European level (thus facilitating the free movement of patients), while, at the same time, respecting the Member States' freedom to organise their social systems, in order to protect the solidarity on which those systems are based.
\end{abstract}

\section{Introduction}

Health care is one of the essential elements of any society. It affects all people, either directly, through treatment, or indirectly, through taxation or contributions. Since it is one of the universal issues which influence electoral outcomes, health care has enormous national political significance. This is probably the reason why it has remained the primary competence of Member States of the EU, with EU competences mainly limited to non-binding measures.

* PhD researcher, KU Leuven Institute for Social Law. The author would like to thank Dr Danny Pieters and Dr Paul Schoukens for their suggestions and insights which contributed to the producing of this article. 
The division of competences is demonstrated by art 168 of the Treaty on the Functioning of the European Union (hereinafter: TFEU), dealing with public health, which recognises the responsibilities of the Member States for the definition of their health policy and for the organisation and delivery of health services and medical care'. ${ }^{1}$ If we, furthermore, take into account that the possibilities of adopting secondary EU legislation in the area of public health are limited to very specific areas, like blood derivatives, quality standards for medicinal products and the like, ${ }^{2}$ we can see that EU Member States have significant legislative freedom to organise their health systems.

A similar situation exists in the area of social security. The legislative measures adopted by the EU in this area 'shall not affect the right of Member States to define the fundamental principles of their social security systems and must not significantly affect the financial equilibrium thereof'. ${ }^{3}$ Furthermore, the adoption of EU secondary legislation in the area of social security is subject to a special legislative procedure, which includes unanimous decision-making by the Council and only the consultation of the European Parliament. ${ }^{4}$ Therefore, it is evident that the Member States have retained essential autonomy to define their own social security systems.

However, the case law of the European Court of Justice has, in the years following Raymond Kohll $v$ Union des caisses de maladie, ${ }^{5}$ expanded the scope of primary law rules on freedom to provide and receive services in this traditionally exclusively national area, in situations where persons travel abroad for the purpose of obtaining health treatment. This development has led to ambiguities about the consequences it could have on the regulation of national health care regulation and the possibilities for individuals to receive social (public) coverage of health treatment obtained in a Member State in which they are not socially protected. Additional ambiguities have been caused by the recent EFTA Court jurisprudence ${ }^{6}$ on patient mobility and the potential adoption of similar argumentation by the Court of Justice. ${ }^{7}$

The aim of this paper is to critically analyse the mentioned case law of the EFTA Court in terms of the profound consequences its reasoning might have on the Member States' freedom to determine their social security coverage of health treatment obtained in Member States in which

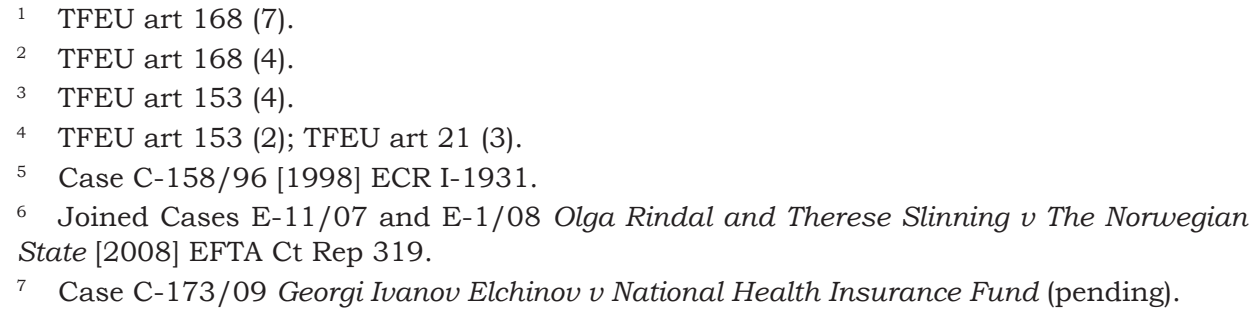


the patients are not socially protected. It is divided into five main parts. The first part describes the development of the EU legal framework on cross-border patient mobility and the main issues of this development in the area of the social security coverage of health treatment obtained in the other EU Member States. The second part deals with the new issues raised by the EFTA Court and its relationship to the Court of Justice case law. The third part deals with the latest attempt to codify the case law by way of EU secondary legislation. ${ }^{8}$ The fourth part analyses the consequences the described European legal framework could have on the national social security systems of the EU Member States, specifically the social security systems of the 'new' Member States of Central Europe, and of Croatia, once it joins the EU. The final part contains proposals for action, both at the EU and the national level, in order to improve legal certainty, while protecting the solidarity on which the social security systems are based.

\section{Current legal framework}

\section{Rules on the co-ordination of social security systems}

When discussing patient mobility within the EU, it is first necessary to analyse the EU rules on the co-ordination of social security systems, which have represented the legal framework for cross-border patient mobility for decades. For a significant period, the main instrument of social security co-ordination between the EU Member States was Regulation $1408 / 71 .{ }^{9}$ It was ultimately replaced by Regulation $883 / 2004,{ }^{10}$ which became applicable with the entry into force of its implementing Regulation $987 / 2009^{11}$ on 1 May $2010 .{ }^{12}$

\footnotetext{
8 Commission (EC) Proposal for a Directive of the European Parliament and of the Council on the application of patients' rights in cross-border health care COM (2008) 414 final, 02 July 2008 (hereinafter: Original Proposal).

9 Regulation (EEC) $1408 / 71$ of the Council of 14 June 1971 on the application of social security schemes to employed persons and their families moving within the Community [1971] OJ L149/2, last amended by Regulation (EC) 1992/2006 of the European Parliament and of the Council of 18 December 2006 amending Council Regulation (EEC) 1408/71 on the application of social security schemes to employed persons, to self-employed persons and to members of their families moving within the Community [2006] OJ L392/1 (hereinafter: Regulation 1408/71); preceded by Regulation (EEC) 3 of the Council of 25 September 1958 on social security for migrant workers [1958] OJ 30/561 (originally: Réglement 3 concernant la sécurité sociale des travailleurs migrants).

10 Regulation (EC) 883/2004 of the European Parliament and of the Council of 29 April 2004 on the coordination of social security systems [2004] OJ L166/ 1 (hereinafter: Regulation 883/2004].

11 Regulation (EC) 987/2009 of the European Parliament and of the Council of 16 September 2009 laying down the procedure for implementing Regulation (EC) 883/2004 on the coordination of social security systems [2009] OJ L284/1.

12 A more detailed overview of Regulation 883/2004 can be found in Franz Marhold, 'Modernisation of European Coordination of Sickness Benefits' (2009) 11 European Journal of
} 
It is important to note that the co-ordination rules do not aim to harmonise national rules in the area of social security. ${ }^{13}$ It is their goal, rather, to provide solutions for legal situations in which a person, due to his/her cross-border movement, comes into contact with several national social security (legal) systems, in which problems may arise, specifically the consequences of losing social security entitlements. What is especially important is that EU co-ordination does not mean replacing the (body of national rules with EU rules; it only affects those national provisions which deal with migrants, specifically by overriding the national rules which are disadvantageous to them. ${ }^{14}$ National social security systems, in the area of health care, are generally free to determine the level and scope of their social security health coverage by themselves.

Due to the different rules the national social security systems use to determine their personal scope of application, positive and negative conflicts of law may occur. ${ }^{15}$ A negative conflict of law arises when a person is living in a Member State which determines the scope of application of its social security system by reference to the conducting of a professional activity (as an employed or self-employed person, for instance), ${ }^{16}$ while working in a Member State whose social security system applies to all its inhabitants. ${ }^{17}$ In this case, if the Member States apply only their national applicability rules, the person will be left without social protection. Since these kinds of possibilities would be detrimental to the mobility of workers within the EU, EU primary law, among its provisions on free movement of workers, contains a specific legal basis designed for the adoption of measures on social security co-ordination. ${ }^{18}$ This legal basis was used

Social Security 119; Frans Pennings, 'Introduction: Regulation 883/2004 - The Third Coordination Regulation in a Row' (2009) 11 European Journal of Social Security 3; Yves Jorens and Filip Van Overmeiren, 'General Principles of Coordination in Regulation 883/2004' (2009) 11 European Journal of Social Security 47; Paul Schoukens and Danny Pieters, 'The Rules within Regulation 883/2004 for Determining the Applicable Legislation' (2009) 11 European Journal of Social Security 81.

13 Vassilis G Hatzopoulos, 'Killing National Health and Insurance Systems but Healing Patients? The European Market for Health Services after the Judgements of the ECJ in Vanbraekel and Peerbooms' (2002) 39 CML Rev 683, 686.

14 Frans Pennings, Introduction to European Social Security Law $\left(4^{\text {th }}\right.$ edn Intersentia, Antwerp 2003) 7.

15 Pennings (n 14) 6.

16 These systems can be characterised as 'professional or occupational social insurances'. See Danny Pieters, Social Security: An Introduction to the Basic Principles $\left(2^{\text {nd }}\right.$ edn Kluwer Law International, Alphen aan den Rijn 2006) 21-22.

17 These systems can be characterised as 'peoples or universal social insurances'. See Pieters (n 16).

18 TFEU art 48, former Article 51 of The Treaty Establishing the European Economic Community (hereinafter: EEC Treaty) and Article 42 of The Treaty Establishing the European Community (hereinafter: EC Treaty). 
to adopt Regulation $1408 / 71$ and subsequently Regulation 883/2004. ${ }^{19}$ The regulations are based on the principle of lex loci laboris (law of the place of work) which means that in cross-border situations (for instance that of the same person living in one Member State while working in another) a person will be subject to the legal system of the Member State in which he/she works, which is the competent state. This is a general rule, with many exceptions. ${ }^{20}$

One of the situations that the co-ordination rules deal with is that of a person socially insured in one Member State (hereinafter: the competent state) who obtains health treatment in another Member State. There are several situations to be distinguished here, the most important of which are sketched below. In all these cases, the treatments are provided according to the rules of the state of treatment (including its tariffs), while the refund, on the other hand, is provided by the competent state.

The basic situations are:

1) A person insured in Member State A with residence in Member State B is entitled to health care in Member State B. The competent institution (health insurer) covers the cost of the foreign treatment according to the foreign tariff (tariff applicable in the state of residence), as though the person was insured in his/her state of residence. The person is also entitled to health care treatment in Member State A when he/she is (temporarily) staying there, under its tariffs. ${ }^{21}$

2) When a person insured in Member State A is (temporarily) staying in Member State B, that person is entitled to necessary health care, 'taking into account the nature of the benefits and the expected length of stay'. The competent institution covers the cost according to the tariff applicable in Member State B, where the health treatment was provided. ${ }^{22}$

3) When a person insured in Member State A travels to Member State $\mathrm{B}$ for the purpose of obtaining health treatment, he/she must ask for authorisation from his/her health insurer in order to obtain social coverage of the treatment. This authorisation must be granted where:

\footnotetext{
19 EEC Treaty art 7 (equivalent to former EC Treaty art 12 and today's TFEU art 18) prohibiting discrimination on the basis of nationality was also used for the original Regulation 1408/71, while EEC Treaty art 235 (equivalent to former EC Treaty art 308 and today's TFEU art 352) was used both for amending Regulation 1408/71 and adopting Regulation $883 / 2004$. EC Treaty art 63(4) (today's TFEU art 79(2)) was used to extend the scope of application of Regulation $1408 / 71$ to third country nationals.

20 Regulation 883/2004 art 11-16; Regulation 1408/71 art 13-17.

21 Regulation 883/2004 art 17-18; Regulation 1408/71 art 19(1), 21(1).

22 Regulation 883/2004 art 19; Regulation 1408/71 art 22(1).
} 
...the treatment in question is among the benefits provided for by the legislation in the Member State where the person concerned resides and where he cannot be given such treatment within a time-limit which is medically justifiable, taking into account his current state of health and the probable course of his illness. ${ }^{23}$

There are also specific rules for the social coverage of health care obtained by pensioners in those three basic situations:

1) A pensioner receiving a pension under the rules of Member State A with residence in Member State B (and not entitled to health care under the rules of Member State B) will receive health care in Member State B if he/she is entitled to health care in Member State A in the case of residence there. The competent institution of Member State A covers the cost of the treatment according to the tariffs applicable in the state of residence. If the pensioner is entitled to health care in more than one Member State (from which he/she receives pensions), social coverage will be provided by the institution of the Member State in which he/she was insured for the longest period of time. ${ }^{24}$

2) A pensioner temporarily staying in Member State C outside his/ her Member State of residence (Member State B) is entitled to necessary health care, as the latter is defined in Regulation $883 / 2004$ art 19, which means 'taking into account the nature of the benefits and the expected length of stay'. The costs are covered by the competent institution of Member State A (from which the pension is paid) according to the tariff of the state of treatment (Member State C). ${ }^{25}$

3) When a pensioner receiving a pension from Member State A travels to Member State B for the purpose of obtaining health treatment, he/she must ask for authorisation from the competent institution of Member State A. The requirements for granting authorisation are the same as for insured persons, and the tariffs of Member State B are applicable. If the pensioner has residence in Member State C, which receives reimbursement from Member State A on

\footnotetext{
23 Regulation 883/2004 art 20; Regulation 1408/71 art 22(2) contained an equivalent provision, but it stated that the authorisation may not be refused when the person cannot be given the treatment within the time normally necessary for obtaining the treatment in question in the Member State of residence, taking into account his current state of health and the probable course of the disease.

24 Regulation 883/2004 art 24; Regulation 1408/71 art 28.

25 Regulation 883/2004 art 27(1); Regulation $1408 / 71$ art 31 provided that these costs were to be covered by the state of residence.
} 
the basis of fixed amounts, Member State $\mathrm{C}$ is considered to be the competent state. ${ }^{26}$

Of all the described situations, this paper focuses on that of a person travelling to another Member State for the purpose of obtaining socially covered health treatment (the prior authorisation procedure), due to the evolving case law of the Court of Justice applying internal market rules in this area. The paper deals with the interaction between the prior authorisation procedure, as defined in the co-ordination rules described above, and the Court of Justice (and EFTA Court) jurisprudence based on the direct application of primary law.

Within the context of prior authorisation, it is important to mention the Court of Justice judgement in Vanbraekel. ${ }^{27}$ This was a case of a Belgian national, Ms Descamps, insured in Belgium, who was unlawfully, according to Belgian rules, refused authorisation (which was found by the Court to fall under Regulation 1408/71) for hospital treatment in France, which she underwent anyway. After obtaining the treatment, she claimed reimbursement from the Belgian insurer. ${ }^{28}$ If the French rules were applicable, she would have been entitled to reimbursement smaller than if the Belgian rules applied.

The Court decided that:

Article 59 of the EC Treaty is to be interpreted as meaning that, if the reimbursement of costs incurred on hospital services provided in a Member State of stay, calculated under the rules in force in that State, is less than the amount which application of the legislation in force in the Member State of registration would afford to a person receiving hospital treatment in that State, additional reimbursement covering that difference must be granted to the insured person by the competent institution. ${ }^{29}$

The wording of the cited paragraph is very general, so one might conclude that every time a patient obtains health treatment abroad, the insurer is obliged to calculate the amount of coverage according to both coverage systems (the co-ordination system based on the state of treatment tariffs, and the primary law system based on the competent state

26 Regulation 883/2004 art 27(3) and art 27(5); Regulation 1408/71 art 22(1)c as interpreted by the Court of Justice in Case 182/78 Bestuur van het Algemeen Ziekenfonds Drenthe-Platteland v G Pierik [1978] ECR 1977 and Case C-156/01 RP van der Duin v Onderlinge Waarborgmaatschappij ANOZ Zorgverzekeringen UA and Onderlinge Waarborgmaatschappij ANOZ Zorgverzekeringen UA v TW van Wegberg-van Brederode [2003] ECR I-7045.

27 Case C-368/98 Abdon Vanbraekel and Others $v$ Alliance nationale des mutualités chrétiennes (ANMC) [2001] ECR I-5363.

28 Ms Descamps who obtained the treatment abroad died in the course of the proceedings and her heirs, namely her husband, Mr Vanbraekel, pursued the action.

29 Vanbraekel (n 27) para 53. 
tariffs, which is analysed in more detail under 2), and apply the one which is more favourable for the patient. This interpretation, of course, leads to practical problems for health insurers in having to make calculations on the basis of both domestic and foreign rules. However, the subsequent case law refined the described reasoning, as demonstrated in 2.5.

Consideration should also be given to Keller. ${ }^{30}$ The case was about a German national, Ms Keller, living in Spain (which was the competent state) who underwent health treatment in Switzerland, where she was referred by German doctors, since her health problems had become evident during her temporary stay in Germany. The question arose about whether the competent institution should reimburse the costs, since it did not grant prior authorisation for treatment in a state outside the EU.

The Court held that, since the competent institution issued an $\mathrm{E}$ 111 form entitling the patient to immediately necessary treatment during a temporary stay abroad, ${ }^{31}$ and an E 112 form authorising health treatment in Germany, it thereby agreed to the application of German rules. This agreement, according to the Court's interpretation of the co-ordination rules (under which the patient is treated according to the law of the state of treatment) means that the state of treatment is bound by the findings of the German doctors regarding the need for urgent (immediately necessary) treatment. The obligation applies even if that treatment is provided outside the EU. ${ }^{32}$

\section{Direct application of primary law}

The Court of Justice has, since 1998, laid down several rulings on the social security coverage of health treatment obtained in the Member States in which the patients are not socially protected. ${ }^{33}$ These judge-

30 Case C-145/03 Heirs of Annette Keller v Instituto Nacional de la Seguridad Social (INSS) [2005] ECR I-2529.

31 Regulation $1408 / 71$ art 22(1)a provided that during a temporary stay abroad a person whose condition necessitates immediate health treatment is entitled to that treatment. This provision was amended by Regulation (EC) 631/2004 of the European Parliament and of the Council of 31 March 2004 amending Council Regulation (EEC) No 1408/71 on the application of social security schemes to employed persons, to self-employed persons and to members of their families moving within the Community, and Council Regulation (EEC) No 574/72 laying down the procedure for implementing Regulation (EEC) No 1408/71, in respect of the alignment of rights and the simplification of procedures, art 1(1). The latter regulation inserted the new provision, according to which the person shall be entitled to health treatments which become necessary during a temporary stay abroad, taking into account the nature of the benefits and the expected length of stay.

32 Keller ( $\mathrm{n} 30$ ) para 53.

33 Case C-120/95 Nicolas Decker v Caisse de maladie des employés privés [1998] ECR I-1831; Case C-158/96 Raymond Kohll v Union des caisses de maladie [1998] ECR I-1931; Case C-157/99 BSM Geraets-Smits $v$ Stichting Ziekenfonds VGZ and HTM Peerbooms v Stichting CZ Groep Zorgverzekeringen [2001] ECR I-5473; Case C-385/99 VG Müller-Faurév 
ments have dealt with the application of free movement rules (namely, freedom to provide and receive services ${ }^{34}$ ) representing 'one of the most dynamic fields of Community law'. ${ }^{35}$

2.1. The first cases in, by now, a long line, were Kohll and Decker. These created quite a storm when they came out, due to their potential implications on the national social security systems, one of the cornerstones of the Member States' policies. ${ }^{36}$ They 'established clearly, for the first time, that the economic rules regarding the free movement of goods and services within the EU could be applied to social security systems. ${ }^{37}$ Kohll was the case of a Luxembourg national, insured with a Luxembourg health insurer, for whose daughter authorisation for orthodontist treatment in Germany was refused. The question was raised before the Court of Justice about the compatibility with the freedom to provide services of national rules that imposed the condition that prior authorisation should be obtained before foreign treatment could be covered.

Decker dealt with the situation of a Luxembourg national, as in Kohll, insured with a Luxembourg health insurer, who was refused the reimbursement of costs of spectacles purchased in Belgium. The reimbursement was refused by the insurer because prior authorisation had not been given. Here, the question arose of compatibility with the free movement of goods of national provisions that imposed the condition that prior authorisation was to be granted before foreign medical products could be covered. ${ }^{38}$

The judgements were rendered on the same day and were based on the same reasoning. At the outset, the Court concluded that the internal market provisions are indeed applicable to social security. It started by

\footnotetext{
Onderlinge Waarborgmaatschappij OZ Zorgverzekeringen UA and EEM van Riet $v$ Onderlinge Waarborgmaatschappij ZOA Zorgverzekeringen [2003] ECR I-4509; Case C-326/00 Idryma Koinonikon Asfaliseon (IKA) v Vasilios Ioannidis [2003] ECR I-1703; Case C-56/01 Patricia Inizan v Caisse primaire d'assurance maladie des Hauts-de-Seine [2003] ECR I-12403; Case C-496/01 Commission of the European Communities $v$ French Republic [2004] ECR I-2351; Case C-8/02 Ludwig Leichtle v Bundesantstalt für Arbeit [2004] ECR I-2641; Case C-372/04 The Queen on the application of Yvonne Watts $v$ Bedford Primary Care Trust Secretary of State for Health [2006] ECR I-4325; Case C-466/04 Manuel Acereda Herrera $v$ Servicio Cántabro de Salud [2006], ECR I-5341; Case C-444/05 Aikaterini Stamatelaki v NPDD Organismos Asfaliseos Eleftheron Epangelmation (OAEE) [2007] ECR I-3185.

34 EC Treaty art 59 (after amendment EC Treaty art 49 and today's TFEU art 56) and EC Treaty art 60 (after amendment EC Treaty art 50 and today's TFEU art 57).

35 Vicki Paskalia, 'Co-ordination of Social Security in the European Union: An Overview of Recent Case Law' (2009) 46 CML Rev 1177, 1202.

${ }^{36}$ For a more detailed summary, see Pedro Cabral 'Cross-Border Medical Care in the European Union: Bringing Down a First Wall' (1999) 24 EL Rev 387.

37 Elias Mossialos and Martin McKee, EU Law and the Social Character of Health Care (Work and Society Series vol 38, Peter Lang, Brussels 2002) 99.

38 EC Treaty art 30 (after amendment EC Treaty art 28 and today's TFEU art 34).
} 
emphasising that the Member States had freedom to organise their social security systems. However, in doing so, the Member States must comply with Community (Union) law, since 'the special nature of certain services does not remove them from the ambit of the fundamental principle of freedom of movement'. ${ }^{39}$ Unfortunately, no additional argumentation was provided.

Furthermore, the Court dealt with the potential paradox that the authorisation procedure, prescribed by the co-ordination rules, could in fact be contrary to primary law. A solution was found which has been debated ever since. The Court interpreted the co-ordination rules as representing only one way of obtaining social security coverage of health treatment obtained in other Member States. This was that authorisation was needed to obtain coverage according to the legislation (including tariffs) applicable in the state of treatment. However, imposing only the co-ordination method represents a barrier to the free movement of goods and freedom to provide services (more precisely, the patient's freedom to travel abroad and receive health services, but the primary law language of 'freedom to provide services' will be used). ${ }^{40}$

The other way, in effect newly established by the Court, allows the patient to travel to another Member State for the purpose of obtaining health treatment, without the need to receive prior authorisation from the health insurer. The latter patient is entitled to reimbursement based on the tariffs of the competent state. ${ }^{41}$ Unlike under the co-ordination rules, ${ }^{42}$ the patient who bases his/her claim for the social coverage of foreign treatment on primary law is obliged in all cases to pay on the spot, while claiming reimbursement a posteriori from the competent state's social insurer.

After determining that making prior authorisation a condition for the reimbursement of all health treatment obtained abroad is contrary to internal market rules, the Court analysed the possible justifications of the national rules in question. First, it dealt with the argument of maintaining the financial balance of the social security system as an overriding reason in the general interest. Here, the Court applied the rule of reason. ${ }^{43}$ The conclusion was that although protecting the financial stability

\footnotetext{
39 Kohll (n 33) para 20.

40 Kohll (n 33) para 35; Decker (n 33) para 36.

41 Kohll (n 33) para 27; Decker (n 33) para 29.

42 There, the procedure depends on the rules of the state of treatment.

43 For the application of the rule of reason, three requirements need to be satisfied in order for the national measure in question to be justified: application without distinction of the national rule in question; the public-interest requirement (overriding reason in the general interest); and proportionality. See to this effect Koen Lenaerts and Piet Van Nuffel, Constitutional Law of the European Union (Sweet and Maxwell, London 2005) 234-236.
} 
of the social security system could represent a ground for justification, reimbursing foreign treatment on the basis of domestic tariffs cannot have significant financial consequences on the social security system. ${ }^{44}$ The Court thus dismissed the national rule as being unnecessary for achieving the invoked objective. ${ }^{45}$

Second, the Court rejected the public health argument (justification provided explicitly by primary $l \mathrm{aw}^{46}$ ) that the quality control of foreign health treatment and medical products can be made only at the time of the request for authorisation (it is too late after the treatment, of course,). The Court's reasoning was based on the fact that the requirements for the providers in the professions (dentists and opticians) in question have been harmonised at the EU level ${ }^{47}$ implying that the quality of health care does not vary significantly between the different Member States. ${ }^{48}$

Third, the Court acknowledged that the protection of a balanced medical and hospital service open to all can also be used as a public health justification for national rules on prior authorisation. However, it dismissed this argument in the concrete case, for the lack of evidence that a balanced medical service is jeopardised by allowing patients to obtain foreign treatment without prior authorisation. Again, the measure was deemed unnecessary in achieving the objective. ${ }^{49}$

The judgements in Kohll and Decker, by directly applying internal market rules in the area of social security, represented a significant change in the relationship between the Member States and the Union, reducing the Member States' freedom to organise their social security coverage. Significantly, they left several questions unanswered. First, since the facts of the cases dealt with non-hospital treatment, it was unclear whether the same reasoning applied also to hospitals. Second, it was unclear whether the Court's reasoning can be applied in the context of benefits-in-kind health care systems and national health services, since the judgements concerned the Luxembourg reimbursement system. ${ }^{50}$

\footnotetext{
44 Kohll (n 33) para 42; Decker (n 33) para 40.

45 Lenaerts and Van Nuffel (n 43) 236.

46 EC Treaty art 56 (after amendment EC Treaty art 46 and today's TFEU art 52) and EC Treaty art 66 (after amendment EC Treaty art 55 and today's TFEU art 62) for services; EC Treaty art 36 (after amendment EC Treaty art 30 and today's TFEU art 36) for goods.

47 Kohll (n 33) para 47; Decker (n 33) para 42.

48 Currently harmonised by Directive (EC) 2005/36 of the European Parliament and of the Council of 7 September 2005 on the recognition of professional qualifications [2005] OJ L255/22.

49 Kohll (n 33) paras 50-52.

50 Social health care systems can, generally, be divided into two main types. Social health insurance, in principle, covers economically active persons, is mainly financed from contributions, and the insurer and the provider are separate entities. National health services (as in the UK) in principle cover all the inhabitants, are financed through taxation, with
} 
Applying the subsequent reimbursement mechanism for foreign treatment could cause serious problems for national health services which are, in principle, free of charge, and, therefore, might not have defined tariffs at all. Finally, the question of the mutual relationship of the two parallel systems of coverage (one based on the co-ordination rules and the other based on the internal market rules of primary law) and their possible convergence was left open.

2.2. Some answers came in Geraets-Smits, delivered on 12 July 2001. Geraets-Smits dealt with two cases of Dutch nationals (Mrs Geraets-Smits and Mr Peerbooms) insured in the Netherlands, who obtained complex hospital health treatment in Germany and Austria. The reimbursement of costs was refused because it was claimed by the insurance funds that the statutory requirements had not been met. The national rules provided for the coverage of treatment in a foreign hospital being subject to prior authorisation. The authorisation would be given if the health treatment was among the benefits for which the sickness insurance scheme of the first Member State assumed responsibility, which was only the case for treatment 'normal in the professional circles concerned'.

Second, it was prescribed that treatment abroad must be necessary for the patient's medical condition, meaning that adequate care cannot be provided without undue delay by a health care provider contracted by the health insurance fund from the Netherlands. The legality of these provisions, in relation to the rules on freedom to provide services, came before the Court.

The Court, at the outset, stated that 'medical activities fall within the scope of Article 60 of the Treaty, there being no need to distinguish in that regard between care provided in a hospital environment and care provided outside such an environment'. ${ }^{51}$ No additional argumentation for this statement was provided.

Furthermore, the Court concluded that, although the health system in the Netherlands was a benefits-in-kind system, internal market rules still applied in the case. ${ }^{52}$ This was contrary to the reasoning of Advocate General Ruiz-Jarabo Colomer, who held that the provisions on the freedom to provide services cannot be applied to the Dutch benefits-in-kind systems, since there is no remuneration for the treatment in question. He emphasised that the patient does not pay for the service by himself/

payer and the provider being a single entity. Insurance systems can further be divided into reimbursement systems, where the patient pays the provider on the spot, subsequently being reimbursed by the insurer, and the benefits-in-kind systems, where the insurer pays the provider directly. The latter system can also be called 'third party payment system'. See Pieters (n 16) 89.

51 Geraets-Smits (n 33) para 53.

52 Geraets-Smits (n 33) para 55. 
herself, while the payments made by insurance funds are based on fixed amounts and are defined in advance, their primary purpose being to finance the providers (such as hospitals) instead of representing a market exchange. ${ }^{53}$ This issue is dealt with in more detail in 2.5.

After determining that internal market rules are applicable in the case, the Court concluded that the contested national rules did represent a barrier to the freedom to provide services, since they deterred patients from applying to health care providers in other Member States. This was decided despite the fact that the Dutch health insurance funds could, potentially, enter into agreements with foreign providers. However, since it was unlikely that significant numbers of foreign hospitals would enter into such agreements, the effective barrier was clear. ${ }^{54}$

Next, the Court analysed the potential justifications for restricting internal market freedom. It accepted that, in the case of hospital treatment, a prior authorisation procedure can be justified for reasons of:

1. Sufficient and permanent access to a balanced range of high-quality hospital treatment in the State concerned. ${ }^{55}$

2. Cost control within the hospital sector. ${ }^{56}$

To see whether the national measure in question could be justified, the Court turned to the content of the authorisation procedure. There, it determined that the requirement for the treatment in question to be necessary within the professional circles concerned was in itself not contrary to EU law. However, the professional circles concerned must not be limited to those of the Netherlands, since that would represent a discrimination of foreign treatment and providers. The criterion must be objective, based on the standards developed by international medical science. ${ }^{57}$

The mentioned reasoning means that a national rule determining coverage not on the basis of precisely defined socially covered treatment and conditions, but on general criteria like 'normal treatment', 'advanced technical treatment', 'necessary treatment', is more likely, in practice, to be contrary to EU law, since it is very hard to define concepts by using international definitions. The reason for the latter claim is the specific nature of the health system, which is tailor-made for the needs at the national level, and the relevant legal terms are defined accordingly.

\footnotetext{
53 Opinion of Advocate General Ruiz-Jarabo Colomer in Geraets-Smits (n 33) delivered on 18 May 2000 para 29.

54 Geraets-Smits (n 33) paras 62-69.

55 Geraets-Smits (n 33) para 78.

56 Geraets-Smits (n 33) para 79. According to the Court, the mentioned arguments are intrinsically linked to the financial balance justification and are, thus, analysed together. See Geraets-Smits (n 33) para 73.

57 Geraets-Smits (n 33) paras 94-98.
} 
When it comes to the second requirement, that of necessity, for granting authorisation, the Court held that:

...authorisation to receive treatment in another Member State may be refused on that ground only if the same or equally effective treatment can be obtained without undue delay from an establishment with which the insured person's sickness insurance fund has contractual arrangements. ${ }^{58}$

In this way, the body deciding on granting authorisation must take into account a wide number of factors. ${ }^{59}$ What is important is that these factors are those of each individual case, thus giving priority to the interests of individual patients applying for authorisation over the interests of the social security systems based on solidarity. The patients who will benefit most from this reasoning are those who are well off, who are able to pay for the foreign treatment on the spot (which patients do not have to do under the co-ordination rules if the state of treatment does not apply the reimbursement system, but which they have to do under the primary law route) and those who have enough time and resources to engage in a possible subsequent legal dispute if the social security institution of the competent state refuses to cover the cost of the foreign treatment.

Furthermore, a person who is seriously ill and in pain can use foreign treatment to bypass those on the waiting list who are in need of treatment more urgently (because they are in more pain, for example) but who are physically unable to travel abroad. ${ }^{60}$ In that hypothetical case, the treatment must be granted, since the individual case which is decided is isolated from the context of the social security system. ${ }^{61}$ In addition, the Court did not explain what happens if the treatment abroad is more effective than the domestic treatment available for the same diagnosis.

The patient cannot go abroad to obtain health treatment which is not covered domestically by his/her social health insurer, since:

...Community law cannot in principle have the effect of requiring a Member State to extend the list of medical services paid for by its social insurance system: the fact that a particular type of medical

\footnotetext{
58 Geraets-Smits (n 33) para 103.

59 Geraets-Smits (n 33) para 104.

60 This argument was put forward in relation to Watts (n 33) by Christopher Newdick, 'Citizenship, Free Movement and Health Care: Cementing Individual Rights by Corroding Social Solidarity' (2006) 43 CML Rev 1645, 1662.

61 For an additional analysis of the relationship between the concept of solidarity and the Court of Justice case law, see Christopher Newdick 'The European Court of Justice, TransNational Health Care, and Social Citizenship: Accidental Death of a Concept?' (2009) 26 Wisconsin International Law Journal 844.
} 
treatment is covered or not covered by the sickness insurance schemes of other Member States is irrelevant in this regard. ${ }^{62}$

Of course, the opposite possibility would be detrimental to the financial sustainability of social health coverage systems, especially in those Member States which are not financially capable of covering the most advanced and expensive health treatment.

2.3. The next important judgement dealing with the prior authorisation procedure was Müller-Fauré. ${ }^{63}$ The case involved two ladies insured in the Netherlands who underwent health treatment in other Member States. Ms Müller-Fauré underwent dental treatment in Germany, while Ms Van Riet was subjected to arthroscopy in Belgium. Both patients obtained their treatment without prior authorisation and reimbursement was denied by their insurers. The question of the legality of the prior authorisation procedure in the context of the freedom to provide services again arose.

The judgement is important because the Court explicitly distinguished between two situations. In relation to hospital treatment, the Court concluded that the prior authorisation requirement is a justified barrier to the free provision of services because of the need to maintain a balanced allocation of hospital resources, which would be jeopardised in the case of an uncontrolled outflow of patients to foreign hospitals. ${ }^{64}$ However, it again emphasised, as part of the 'undue delay' requirement, the need to look at the individual situation of the patient concerned, taking into account his/her medical history, degree of pain and the ability to conduct professional activity. ${ }^{65}$

Regarding non-hospital treatment, the Court held that the prior authorisation requirement cannot be justified by the need to maintain financial balance in the social security system. The argument was that it is unlikely that significant numbers of patients would travel to seek non-hospital health care abroad, because of the linguistic barriers, distances, costs and the lack of information. ${ }^{66}$ However, precise criteria on how to distinguish between hospital and non-hospital treatments were not laid out. ${ }^{67}$

\footnotetext{
62 Geraets-Smits (n 33) para 87.

63 For a more detailed summary, see Anne Pieter van der Mei, 'Cross-Border Access to Health Care within the European Union: Recent Developments in Law and Policy' (2003) 10 European Journal of Health Law 369, 372-375.

64 Müller-Fauré (n 33) para 91.

65 Müller-Fauré (n 33) para 90.

66 Müller-Fauré (n 33) para 95.

67 Including the Court' $\mathrm{s}$ ambiguous statement that 'certain services provided in a hospital environment but also capable of being provided by a practitioner in his surgery or in a health centre could for that reason be placed on the same footing as non-hospital services' from Müller-Fauré (n 33) para 75.
} 
The complete prohibition of the prior authorisation requirement for non-hospital services has consequences on the way the contracting of health care non-hospital providers is organised in Member States. The Court of Justice jurisprudence, by obliging the competent state to cover the treatment obtained by foreign providers, puts domestic contracted providers, who are therefore subject to various controls, in a position similar to that of foreign (non-contracted) providers, who are not subject to those controls. ${ }^{68}$

If a Member State is operating an exclusive contracting system, where contracts are concluded with a limited number of providers, domestic non-contracted providers, who are in an equivalent position to foreign providers as regards controls and regulations, are effectively discriminated against. ${ }^{69}$ Discrimination occurs because the Member States are still, under EU law, free to limit (or exclude) the social coverage of treatment obtained from domestic non-contracted providers.

2.4. In Inizan, the Court had to deal with the relationship between the system of social security coverage of foreign health treatment based on co-ordination rules, and the system based on the primary law provisions on freedom to provide services. The Court concluded that the co-ordination rules, which prescribe the mandatory prior authorisation procedure, are not contrary to primary law, because they offer the possibility for the patient to receive higher social coverage (under the rules of the state of treatment) than under primary law (where the domestic rules of the competent state are applicable). ${ }^{70}$

Furthermore, the Court aligned its interpretation of the co-ordination rules and primary law, regarding the conditions for granting prior authorisation. It emphasised that authorisation, under the co-ordination rules, must be granted when an equally effective treatment cannot be provided without undue delay in the state of residence, taking into account the factors mentioned by the Court within the context of the freedom to provide services in Müller-Fauré (namely, his/her medical history, degree of pain and the ability to conduct a professional activity). ${ }^{71}$

\footnotetext{
68 Yves Jorens, Michael Coucheir and Filip Van Overmeiren, Access to Health Care in an Internal Market: Impact for Statutory and Complementary Systems (Volume 18 Bulletin luxembourgeois des questions sociales, Luxembourg, 2005) 31.

69 Jorens, Coucheir and Van Overmeiren (n 68) 31.

70 Inizan (n 33) para 21.

${ }^{71}$ Inizan (n 33) para 46. This case is also important because it applied the Müller-Fauré logic of allowing the prior authorisation requirement for hospital treatments where the competent state's system is not a benefits-in-kind, but a reimbursement system. See Vassilis Hatzopoulos, 'Health Law and Policy: The Impact of the EU' in Grainne de Burca (ed), EU Law and the Welfare State: In Search of Solidarity (OUP, Oxford 2005) 133.
} 
2.5. Watts was the first judgement in the Court's jurisprudence on the application of the freedom to provide services rules on social security coverage of foreign treatments to deal with the UK National Health Service (hereinafter: NHS). ${ }^{72}$ The case was about a British national (and resident) who underwent hip replacement surgery in France. Prior to the treatment, authorisation for the treatment in France was refused by the relevant NHS body (Bedford Primary Care Trust), since, in their view, she could have received treatment in the UK within the government's NHS Plan targets, and thus without undue delay. After obtaining the treatment, Mrs Watts sought reimbursement, which gave rise to the proceedings. The Court found that:

...Article 49 EC applies where a patient such as Mrs Watts receives medical services in a hospital environment for consideration in a Member State other than her State of residence, regardless of the way in which the national system with which that person is registered and from which reimbursement of the cost of those services is subsequently sought operates. ${ }^{73}$

It is visible from the above statement that it is the patient-provider relationship in the state of treatment, and not the patient-provider or insurer-provider relationship in the competent state, which is the crucial factor for the application of the freedom to provide services provisions.

There have been several attempts to explain the applicability of the free provision of services rules to social security coverage of foreign health treatment from the point of view of the social security system which provides the coverage (the system of the competent state). ${ }^{74}$ The main argument is that there can be no remuneration in the case of health care systems in which the providers and payers are not separate, independent entities (notably, the NHS).

Another argument has been put forward based on the distinction between 'supply-side subsidy' and 'demand-side subsidy'. Supply-side subsidies are given by the state to the provider, and the amount is calculated by taking into account various circumstances, which may include specific treatment or the number of patients. The recipient finally pays an

\footnotetext{
72 For a more detailed explanation of the judgment, see Mel Cousins, 'Patient Mobility and National Health Systems' (2007) 34 Legal Issues of Economic Integration 183.

73 Watts (n 33) para 90.

74 Opinion of Advocate General Ruiz-Jarabo Colomer in Geraets-Smits (n 53) para 29; Gareth Davies, 'Welfare as a Service' (2002) 29 Legal Issues of Economic Integration 27, 37; Mark Flear, 'Case C-385/99 V.G. Müller-Fauré v. Onderlinge Waarborgmaatschappij O.Z. Zorgverzekeringen U.A. and E.E.M van Riet v. Onderlinge Waarborgmaatschappij Z.A.O. Zorgverzekeringen, Judgement of the Court of 13 May 2003' (case note) (2004) 42 CML Rev 209, 221; TK Hervey and JV McHale, Health Law and the European Union (Law in Context Series, CUP, Cambridge 2004) 136.
} 
amount which is significantly lower than the market value of the service provided. In contrast, demand-side subsidies are based on assistance with costs, meaning that the recipient of a service initiates the transaction whose cost is covered by the payer (insurer). Therefore, the amount paid represents the real value of the service but, more importantly, the entire transaction, the flow of money, is controlled by the free will of the individual, giving a market character to the transaction, making internal market rules apply. ${ }^{75}$

The Court of Justice clarified the situation in Watts. It decided that the way in which the national system reimbursing the costs is organised is irrelevant, ${ }^{76}$ and that the only important factor is whether the transaction in the Member State of treatment represents the real market value of the service. ${ }^{77}$ Therefore, the relationship among the payer of the health service, the patient and the provider in the competent state has no bearing on the applicability of internal market rules. Since EU primary law applies only in the situation where the patient pays the provider directly and then seeks reimbursement from the competent institution, the payer (patient)-provider relationship in the state of treatment is crucial in defining the applicability of internal market rules.

This logic makes sense from the internal market point of view, but is questionable from the social security aspect. It uses an extraordinary situation, of a patient being in 'no man's land' between two social security systems (which is the only situation in which this logic can apply), to define the fundamental relationship between market integration and the national systems of social security.

However, the relevant situation is only temporary, since the patient subsequently returns home to claim reimbursement, the amount of which is calculated on the basis of the standard relationship between the competent institution and the patient (in the case of the NHS, the standard relationship involving full coverage). It is paradoxical that a situation which is atypical for an insurer-patient relationship leads to reimbursement based on a standard relationship, the logic of which is contrary to internal market logic. In that standard relationship, the service is provided free of charge and is based on a supply-side subsidy, with the payer and the provider being, essentially, one entity (in the case of national health services).

\footnotetext{
75 Gareth Davies, 'Competition, Free Movement, and Consumers of Public Services' (2006) 17 European Business Law Review 95, 98-100.

76 Interpretation supported by Johan W van de Gronden, 'Cross-Border Health Care in the EU and the Organization of the National Health Care systems of the Member States: The Dynamics Resulting from the European Court of Justice's Decisions on Free Movement and Competition Law' (2009) 26 Wisconsin International Law Journal 705, 711.

77 Watts (n 33) para 90.
} 
Next, the Court explicitly aligned interpretation of the term 'undue delay' in the context of the co-ordination rules and of the free provision of services. ${ }^{78}$ In addition, the Court restated ${ }^{79}$ that the existence of waiting lists is in itself not sufficient for a person to be refused authorisation. ${ }^{80}$ In that sense, the Court pointed out that the waiting lists themselves need to be formed in a way that allows for the health treatment to be provided within the time which is acceptable in the light of an objective medical assessment of the clinical needs of the person concerned' ${ }^{81}$

With this statement, the Court did, seemingly, make an effort to legitimise the existence of waiting lists as a justification for imposing a barrier on the free provision of services. However, there is no real balancing here between the interests of the individual patient and the interests of the social security system (protecting the patients as a collective, including those who are not able to travel abroad, or who are not informed of the possibilities to go abroad). The Court explicitly stated that, if the waiting time exceeds the 'medically acceptable waiting time', authorisation must be granted. ${ }^{82}$ The fact that there may be more urgent cases not asking for authorisation (as indeed there will be, since authorisation will be requested precisely to bypass those who are higher on the list) is not taken into account, and neither is the fact that those patients may receive treatment later (than originally envisaged) because of the redirection of funds into covering foreign treatment.

As mentioned in 2.2, ${ }^{83}$ the Court of Justice puts the needs of an individual patient first. This is in line with the objective of promoting freedom to provide and receive services within the EU. However, it must be taken into account that the case law in practice promotes only the freedom of one category of patients to receive services, namely those who are financially capable of paying the provider on the spot, to be subsequently reimbursed by the competent institution. Those who are unable to do so are not helped; on the contrary, they can find themselves in a worse position than they were originally in. Funds that would originally have been used to cover the most urgent treatments are directed to the less urgent cases of well-off people travelling abroad.

The consequence of the Court's approach is that it affects the distribution choices made by the national social security systems, thereby diminishing the power of the Member States to organise their social systems. To describe these choices as being of a purely economic cha-

\footnotetext{
78 Watts (n 33) para 60.

79 Stated in Müller-Fauré (n 33) para 92.

80 Watts (n 33) para 63.

81 Watts (n 33) para 68.

82 Watts (n 33) para 72.

83 Originally by Newdick (n 60).
} 
racter is contrary to the very social purpose of social security. Criteria determining priority treatments are, generally, based on an assessment of a person's medical condition (instead of his/her ability to pay for the treatment), thereby reflecting the principle of solidarity. ${ }^{84}$ Therefore, the overall position of patients is not strengthened, since only some of them are made better off, at the expense of others, and, in the end, the number of covered health procedures within the whole of the EU, including both treatments abroad and purely domestic treatments, will not rise, but the order of priorities will simply be reshuffled. ${ }^{85}$

Another important aspect of Watts is that it refined the rule that the patient is, between the two parallel systems (co-ordination and freedom to provide services), entitled to the more beneficial coverage based on the freedom to provide services. The Court distinguished between two situations. If the cost of the treatment is higher in the competent state than in the state of treatment, the institution of the competent state needs to provide the higher reimbursement, up to the level of the real cost of the treatment (which the patient paid to the provider). ${ }^{86}$ If the cost is higher in the state of treatment, the institution of the competent state pays the amount that it would have paid if the treatment was provided by the competent state provider, and no more. ${ }^{87}$ This applies to the situation where the competent state offers the treatment free of charge (like the NHS, meaning effectively $100 \%$ coverage), while the state of treatment covers only part of the costs (the often used co-payments mechanisms). Whether this rule (a limit on the level of the actual cost) can be translated to the other combinations of competent state/state of treatment, and thus potentially conflicting with Vanbraekel, remains questionable. ${ }^{88}$

Furthermore, the Court explained the coverage of travel and accommodation costs. The co-ordination rules do not entitle the patient to coverage of these costs, but he/she can claim them on the basis of the free movement rules. ${ }^{89}$ Since, under the free provision of services rules,

\footnotetext{
84 Newdick (n 60) 1662-1663.

85 There is also an argument that the real motivation behind the case law is, essentially, a power struggle, shifting the regulatory competence in the field of health care to the EU level. See to this effect Scott L Greer, 'Migration of Patients and Migration of Power: Politics and Policy Consequences of Patient Mobility in Europe' (2009) 26 Wisconsin International Law Journal 908.

86 Watts (n 33) para 131.

87 Watts (n 33) para 132.

88 If Vanbraekel logic can be applied outside the specific context of that case, namely the unlawful refusal of prior authorisation.

89 Watts (n 33) para 138. Under new Regulation 987/2007 art 26(8): 'Where the national legislation of the competent institution provides for the reimbursement of the costs of travel and stay that are inseparable from the treatment of the insured person, these costs for the person concerned and, if necessary, for a person who must accompany him/her, shall be assumed by this institution when an authorisation is granted in the case of treatment in another Member State.'
} 
the competent state provisions are applicable, the patient is entitled to the reimbursement of travel costs if that right is granted for treatment within the competent state (thus avoiding disadvantageous treatment of health care abroad)..$^{90}$

Finally, the Court dismissed the possibility that the primary law obligation to respect the Member States' responsibilities for the organisation and delivery of health services is contrary to the case law on the social security coverage of foreign health treatment, because the case law takes into account the need to maintain the financial balance of social security systems. ${ }^{91}$

2.6. The last judgement by the Court on the application of the free provision of services rules on the social security coverage of health treatment obtained outside the competent state was Stamatelaki. ${ }^{92}$ It dealt with the Greek rules prohibiting the reimbursement of health treatment provided by foreign private hospitals, except for children under 14 years of age.

The Court found that the rules in question gave preferential treatment to private non-contracted hospitals in Greece, because the existence of an emergency was an exception to the no coverage rule for Greek non-contracted private hospitals, but not for foreign non-contracted private hospitals. ${ }^{93}$ This discrimination of foreign private hospitals, therefore, constituted a violation of the freedom to provide services rules, even more clearly than was the case with the indistinctly applicable measures that imposed prior authorisation as a requirement for all treatment by non-contracted providers (Geraets-Smits).

\section{Important ambiguities}

3.1. The first important issue to be dealt with is that of the Member States' autonomy to define which health care treatments are covered by their social security systems. One interpretation of the case law, namely Geraets-Smits, is that 'all European citizens will have the right to a package of comparable heath services throughout the European Union'. ${ }^{94}$

\footnotetext{
90 Watts (n 33) para 140; confirmed by the Court in Acereda Herrera (n 33) para 38.

91 Watts (n 33) para 147. It has also been stated in the literature that the Court takes into consideration the consequences of its interference in the national welfare systems by allowing certain grounds for justification of barriers to free movement. See Koen Lenaerts and Tinne Heremans 'Contours of a European Social Union in the Case-Law of the European Court of Justice' (2006) 2 European Constitutional Law Review 101, 114.

92 [2007] ECR I-3185.

93 Stamatelaki (n 33) para 27.

94 Herman Nys, 'Comparative Health Law and the Harmonization of Patients' Rights in Europe' (2001) 8 European Journal of Health Law 317, 318.
} 
What is the meaning of comparable? If this is to be interpreted as the same package of essentially the same services, then that would represent a true revolution in the social health care systems within the EU. Could this include the right to the highest level of health services, present only in certain of the Member States with better overall standards? This would mean that a patient from Bulgaria, for instance, would be entitled to the same health treatment as a German patient and could, thus, travel to those Member States which offer the treatment in question.

However, this interpretation seems a bit tenuous for two reasons: first, the Court explicitly stated that EU law does not require the Member States to extend the coverage of their social security health systems. ${ }^{95} \mathrm{Se}-$ cond, the case in which the Court emphasised the need to use international standards in determining the health treatments one is entitled to was based on very specific national rules which used the ambiguous criterion of 'normal' treatment for entitlement. It is a completely different situation in Member States with lists of specifically enumerated treatments which are socially covered. This diversity can hardly be overcome by anything except EU level legislation, ${ }^{96}$ which is hard to contemplate since the unanimity requirement still applies for adopting legally binding measures in the field of social security. ${ }^{97}$

Since there is no harmonisation at the EU level and it is not very likely (due to the division of legislative social security competences ${ }^{98}$ ) that there will be one soon, there is a lot of legal uncertainty in this field. One possibility is to use the legal bases for harmonising the internal market, but the diversity of social security systems would still represent a major obstacle to harmonisation, and its validity in terms of the division of competences between the Member States and the EU would, probably, be challenged. ${ }^{99}$

3.2. The second important aspect of the case law concerns the distinction between hospital and non-hospital services (treatments). A solution was proposed in the literature for cases in which there are different definitions of 'hospital service' in the competent state and the state of treatment. According to this proposal, those treatments would be classified as non-hospital, except where there are reasons of general interest

\footnotetext{
95 Geraets-Smits (n 33) para 87.

96 Since Member States are free to organise their own social security systems. See Kohll (n 33) para 18.

97 TFEU art 153(2); TFEU art 21(3).

98 Specifically, TFEU art 153(2) allows for the adoption of directives setting up 'minimum requirements for gradual implementation', with a unanimity requirement.

99 Due to the fact that Member States have the autonomy to organise their social security and health systems, which is recognised by both the Court in Kohll (n 33) and the primary law in TFEU art 153(4) for social security, and TFEU art 168(7) for public health.
} 
(namely the need for planning) to classify them as hospital services, and, thus, to impose the prior authorisation procedure. ${ }^{100}$

There are some problems in relation to the described proposal. For a start, it is not clear why the state of treatment definition should be given priority, except to avoid the competent state deliberately preventing people from going abroad. Perhaps there should be a little more confidence in the rationality of the social security bodies, since the primary purpose of social systems is to protect individuals, not to deprive them of the best possible treatment.

Next, the problem is emphasised here of practically proving that the prior authorisation procedure for certain treatment is needed to facilitate planning and to maintain the financial stability of the system. It can be argued that the Court used the hospital - non-hospital distinction to avoid complex economic analyses of the whole of social health care systems in order to determine the potential consequences of patient outflows. This interpretation is supported by the fact that the Court did not go into determining possibly less restrictive measures for the free provision of services than the prior authorisation rules. It is very questionable if serious analyses can be carried out for every specific case, taking into account that the effects of new developments become visible in large social security systems only after several years.

It is also important to note that a question arose about the status (as hospital or non-hospital) of health spas. ${ }^{101}$ The case was about a German rule which imposed additional requirements for the reimbursement of travel and accommodation costs for foreign treatment, when compared to domestic treatment. Therefore, the reimbursement of these additional costs for a treatment in Italy was refused, even though the cost of the treatment itself was reimbursed. The Court decided that the measure was incompatible with the freedom to provide services. ${ }^{102}$

It has been suggested that Leichtle should be interpreted as putting spa treatments outside the ambit of hospital services, thus disallowing the prior authorisation procedure to be imposed. ${ }^{103}$ Nevertheless, some of its aspects need to be emphasised. The Court did not explicitly rule out prior authorisation (recognition of eligibility), but dismissed one of the conditions that was attached to it. On the other hand, in the case of hospital services, it was not required for Member States to prove concretely the existence of financial justifications (this was assumed, and the main

\footnotetext{
100 Flear (n 74) 225.

101 Leichtle (n 33).

102 Leichtle (n 33) para 51.

${ }^{103}$ Vassillis Hatzopoulos and Do Thien Uyen, The Case Law of the ECJ Concerning the Free provision of Services: 2000-2005' (2006) 43 CML Rev 923, 939.
} 
issue became the needs of the individual patient), while it was required in Leichtle ${ }^{104}$ for spas.

In addition, it must be taken into account that the costs of the treatment itself had already been reimbursed; so, it was harder to use the argument that the reimbursement of travel and accommodation costs could endanger the financial stability of the system, while the coverage of the treatment itself (albeit lower than the travel and accommodation costs) could not. It is also important to note that the German rule attached special conditions to the coverage of additional costs of cure outside Germany, thereby directly treating foreign treatments less favourably than domestic ones.

Thus, a lot of uncertainty still remains in distinguishing between hospital and non-hospital care within the meaning of the Court of Justice case law. A solution has been proposed to alleviate some of that uncertainty, by way of using a Commission Recommendation enumerating an exhaustive list of treatments that are to be considered hospital treatments, and another list which would contain non-hospital treatments. ${ }^{105}$

The basic approach of the latter proposal should be supported, but the choice of instrument is questionable. This is so because the recommendation would bypass the procedures for adopting legally binding instruments, which are more appropriate to deal with the issue. The basis for the latter claim is the fact that the purpose of the proposed recommendation would be to represent an interpretative tool, probably also to be used by the Court of Justice. This tool would be employed to interpret the case law relating to the application of primary law in the very delicate spheres of health care and social security.

Since primary law, as interpreted by the Court, is legally above EU secondary legislation, it would be appropriate to use an instrument which involves at least equal guarantees of democratic participation and public scrutiny as in the case of secondary legislation. Furthermore, this would help to reduce possible criticisms that the Court of Justice is assuming the role of legislator in the area of the social security coverage of crossborder health care. Moreover, defining hospital and non-hospital health care at the EU legislative level would further legitimise the Court's jurisprudence in the field. It would thereby support the hospital - non-hospital distinction as relevant in defining social coverage of health treatment obtained abroad.

\footnotetext{
${ }^{104}$ Leicthle (n 33) paras 37-51.

${ }^{105}$ Pedro Cabral, 'The Internal Market and the Right to Cross Border Medical Care' (2004) 29 EL Rev 673, 686.
} 
Another possibility is to use the non-binding instruments of encouraging co-operation between the Member States. This solution would facilitate dialogue between the social security systems, a big gain for individual cross-border patients, because all the numerous practical complications cannot be solved through top-down EU legislation. It is especially important to note that the problem of distinguishing hospital and non-hospital care emerges only if there are different definitions in the state of treatment and in the competent state. Successful practical co-operation would solve the latter problem. Furthermore, using binding rules could cause opposition from social security systems, as a result of the EU regulating this traditionally national legal area.

Therefore, there are several options, each with advantages and flaws. It seems, however, that the worst choice would be to use an approach which would include both the flaw of putting undue pressure on national social security systems (thus inciting their opposition) and the flaw of weak democratic participation.

3.3. There is still a great deal of legal uncertainty regarding one of the crucial issues of the social security coverage of health treatment obtained abroad, that is, the applicable tariffs. Is Vanbraekel to be considered as the general rule (that the patient is always entitled to the higher of the two tariffs), or Watts (that the reimbursement will not be higher than the actual cost of the foreign treatment)? ${ }^{106}$

It is necessary to distinguish between two elements here. One is the price (cost) of the treatment, and the other is the coverage. In Watts, the competent state offered $100 \%$ coverage (free of charge treatment in the $\mathrm{UK})$, while this was not the case in the state of treatment (France). The Court decided that, if the cost of the equivalent treatment in the competent state is higher than the cost of the foreign treatment, the institution of the competent state needs to provide the higher reimbursement, up to the level of the real cost of the foreign treatment. ${ }^{107}$ In Vanbraekel, the Court held that the patient is entitled to the most advantageous coverage (the question being whether this reasoning is limited to the specific facts of that case, namely the unlawful refusal of authorisation). ${ }^{108}$

What happens if the level of coverage (let us say $80 \%$ of the cost of the treatment) is lower in the competent state than in the state of treatment (let us say $100 \%$ of the cost), but the treatment is more expensive

\footnotetext{
106 The question of the applicability of free provision of services rules and the level of coverage has also been raised within the context of social coverage of health treatments during a temporary stay abroad. See Opinion of Advocate General Mengozzi in Case C-211/08 European Commission v Kingdom of Spain delivered on 25 February 2010 (pending).

107 Watts (n 33) para 131.

108 Vanbraekel (n 33) para 53.
} 
in the competent state than in the state of treatment? When the calculation is made, taking into account both the cost and the coverage of equivalent treatment in the competent state, the reimbursement is higher than if we take into account both the actual cost and the coverage in the state of treatment. Does the Watts reasoning (a limit on the level of the actual cost of the treatment) apply in this situation, since the wording is limited to situations in which the coverage is higher in the competent state?

If Vanbraekel applies, then, presumably, reimbursement should be based on the price and the cost of equivalent treatment (equivalent to the actual treatment provided) in the competent state, with no reference (and thus no limit) to the actual cost of the treatment. On the other hand, how is it possible to determine what exactly 'equivalent treatment' is, especially if one of the concerned states offers different (more advanced) treatment for the same diagnosis from the other?

\section{A revolution?}

\section{Rindal/Slinning}

At the end of 2008, the European Free Trade Association (hereinafter: EFTA) Court, having jurisdiction with regard to EFTA States which are parties to the Agreement on the European Economic Area (hereinafter: EEA Agreement), rendered a judgement in Rindal. ${ }^{109}$ It concerned two joined cases dealing with the question of patient mobility and the social coverage of health treatments obtained outside an EEA Member State (Norway). The question arose whether the national rules on social security coverage were contrary to the EEA Agreement provisions equivalent to the EU primary law provisions on freedom to provide services. ${ }^{110}$

Ms Olga Rindal, a resident of Norway (Norway being the competent state for her social health care coverage) sustained injuries in a car accident resulting in whiplash and back pain. After a decade of torment, and unsuccessful surgery in Norway, Ms Rindal underwent two operations in Germany which improved her state of health. After that, she sought reimbursement of the cost of the treatments from the competent institution in Norway. Her application concerning neck surgery was refused, on the grounds that it was not an internationally recognised treatment for Ms Rindal's condition. Reimbursement of the cost of the operation on her back was also refused, this time because Ms Rindal was not entitled to a new operation in Norway at the relevant point of time.

\footnotetext{
109 Joined Cases E-11/07 and E-1/08 Olga Rindal and Therese Slinning $v$ The Norwegian State [2008] EFTA Ct Rep 319.

${ }^{110}$ EEA Agreement art 36 and EEA Agreement art 37.
} 
Ms Slinning, also a Norway resident (Norway being the competent state for her social health care coverage) suffered a traffic accident which resulted in serious brain injury. For that reason she underwent neurological treatment in Denmark. Her application in Norway for social coverage of the treatment obtained in Denmark was rejected. It was claimed by the relevant body that the treatment in question was an experimental/ test treatment and, therefore, not subject to coverage. Furthermore, it was stated that adequate treatment was offered in Norway, although this was not as comprehensive and intensive as the foreign treatment. Even more importantly, it was concluded that the domestic treatment should be given priority, although the foreign treatment was possibly more advanced.

The first issue dealt with the coverage of experimental/test treatments (according to international medicine ${ }^{111}$ ) obtained abroad. The EFTA Court concluded that, if the experimental treatment is not covered in the competent state, there is no obligation to cover the expenses of foreign experimental treatment. ${ }^{112}$ However, if the treatment is covered in the competent state, and additional conditions are imposed for undergoing the said treatment abroad, those conditions represent a restriction on the free provision of services. ${ }^{113}$ Thus, the EFTA Court emphasised the principle that Member States (in this case, EEA Member States) are entitled to define for themselves whether experimental health treatments are to be socially covered. The condition is, however, that, once those treatments are defined, there can be no discrimination between domestic and equivalent foreign treatments.

In addition to the described principle, the EFTA Court stated that some justifications for limiting coverage of foreign treatments, and thereby treating them less favourably than domestic treatments, are possible. ${ }^{114}$ The essential justification is, again, the protection of the financial balance of the social security system, connected to the objective of sustaining a balanced medical and hospital service open to all. ${ }^{115}$ Since the relevant treatment in Ms Slinning's case was offered in the competent state as part of a medical research programme in limited circumstances, the EFTA Court concluded that the need to maintain the research was adequate justification for limiting reimbursement of corresponding foreign treatments. This conclusion was reached due the fact that:

\footnotetext{
111 Rindal (n 109) para 27.

112 Rindal (n 109) para 46.

113 Rindal (n 109) para 47.

114 Rindal (n 109) para 55.

115 Rindal (n 109) para 55.
} 
It may have negative consequences ... if the fact that the costs for such treatment in domestic hospitals are borne as part of the social security system would mean that any patient who had not been offered such treatment could then seek out such treatment abroad and get the costs reimbursed. Even if that specific experimental or test treatment was also carried out in the patient's home State, a right for patients, who had not been selected for the experiment or test, to receive the treatment abroad and get reimbursed may lead to a reluctance in providing experimental and test treatment and thus seriously undermine medical research. ${ }^{116}$

Therefore, a Member State can refuse to socially cover foreign treatment that is not recognised (by international medicine) if the health treatment in question is not provided by that Member State or is provided only as part of a research project.

The second issue dealt with the question of whether a Member State can refuse to cover foreign recognised treatment if adequate treatment is available in due time domestically. Here, the EFTA Court distinguished between two different situations.

If an adequate domestic treatment is available in due time (justifiable in medical terms, taking into account the patient's individual condition) and the foreign treatment is equally effective, the Member State can refuse to cover the expenses of the foreign treatment. ${ }^{117}$ This rule applies even when the foreign treatment is available sooner than the domestic treatment. ${ }^{118}$

Therefore, some limitations are imposed on the possibility for patients suffering from less severe medical conditions bypassing more urgent cases by going abroad. As the EFTA Court pointed out, the obligation to cover treatments which are not yet necessary for the patients 'would drain resources away from other fields, as there would be a need to allocate funds to pay for more treatments, within a given period, than medically necessary. ${ }^{119}$ On the other hand, if the foreign treatment is in fact more advanced, according to international medicine, than the adequate domestic treatment, 'the State may no longer justify prioritising its own offer of treatment. ${ }^{120}$

The last sentence can have profound consequences on Member States' freedom to organise their social security systems. The most impor-

\footnotetext{
${ }_{116}$ Rindal (n 109) para 58.

${ }^{117}$ Rindal (n 109) para 80.

${ }_{118}$ Rindal (n 109) para 80.

119 Rindal (n 109) para 80.

${ }^{120}$ Rindal (n 109) para 83.
} 
tant aspect is that the application of the principle according to which EEA law does not require a Member State 'to extend the range of medical services paid for by its social security system'121 is significantly limited.

The concept of a 'medical service' here does not seem to correspond to the concept of 'health treatment' (back surgery, for instance), given a certain diagnosis, since the foreign more effective treatment is, in fact, not the same treatment as the domestic, less advanced, treatment for the same condition. Medical service, as understood by the EFTA Court, obviously represents diagnosis (the disease, or the medical condition), like whiplash, or an eye tumour. Therefore, the EEA Member States are free to define the medical conditions, the diseases they cover, but cannot limit the choice of treatments for those diseases, once the diseases are among those that are covered. If Member State A's rule stipulates that it will cover the costs of treating chronic diseases, this should be translated as meaning 'the most advanced treatment for chronic diseases available in any of the EEA Member States'.

What happens if a Member State does not use (only) medical conditions as the criteria for defining the scope of its social security health coverage, but its rules describe in detail the precise health treatments its social system covers? Can the patient receive coverage of a foreign treatment that is more advanced than the one specified by the competent state's rules for the same disease? The EFTA Court recognises the Member States' right to exclude certain treatments from coverage, on the basis of objective, non-discriminatory criteria. ${ }^{122}$ However, it seems this statement relates to defining covered medical conditions, while it is unclear which criterion applies for treatments that are enumerated in detail.

Does the same reasoning apply within the context of the co-ordination rules, taking into account the Court of Justice applying the same criteria (under the co-ordination rules and free movement rules) in defining 'undue delay'?123 This is especially significant, since it would mean the coverage of more advanced (and, presumably, more expensive) foreign

\footnotetext{
${ }_{121}$ Rindal (n 109) para 82; The equivalent principle was stated by the Court of Justice in Case C-157/99 BSM Geraets-Smits $v$ Stichting Ziekenfonds VGZ and HTM Peerbooms $v$ Stichting CZ Groep Zorgverzekeringen [2001] ECR I-5473 para 87.

${ }^{122}$ Rindal (n 109) para 82. The principle stems from Case 238/82 Duphar BV and others $v$ The Netherlands State [1984] ECR 523 para 22 concerning the exclusion of certain medicines from the social package. The reason for the Court's conclusion that there was no breach of free movement of goods rules was based on the fact that the equally effective, but cheaper, medicines were covered. The Court, however, followed different reasoning in finding an obstacle to free movement of goods in Case C-38/03 Commission of the European Communities $v$ Kingdom of Belgium [2005] OJ C57/6 concerning the social coverage of wheelchairs.

${ }^{123}$ Case C-372/04 The Queen on the application of Yvonne Watts $v$ Bedford Primary Care Trust Secretary of State for Health [2006] ECR I-4325 para 60
} 
treatments on the basis of foreign tariffs. The reasoning of giving priority to the more effective treatment was previously applied, concerning Regulation 1408/71, in Pierik, which led to the amendment of the coordination rules to exclude such a possibility. ${ }^{124}$

Finally, will the Court of Justice adopt the same reasoning as the EFTA Court in its jurisprudence? ${ }^{125}$ Answering these questions seems crucial for the future of patient mobility in the EU. If more advanced foreign treatments, not available in the competent state, must be covered, what is left of the competent state's freedom to decide what to exclude from the social package? Therefore, the relationship between the Member States' freedom to decide on the exclusion of certain treatments from coverage and the patients' freedom to receive more advanced foreign treatments is an essential issue. Let us hope that future judgements, by both the EFTA Court and the Court of Justice, will offer some guidance in this respect.

\section{Elchinov}

The most recent case to come before the Court of Justice concerns a Bulgarian patient (Bulgaria being the competent state) who obtained health treatment in Germany. Mr Elchinov was diagnosed with a tumour in his eye. Unfortunately, the most advanced treatment available in Bulgaria for Mr Elchinov's diagnosis was in fact surgery to remove the eye. This treatment is covered by the national rules, which stipulate that a patient is entitled to social coverage of 'other eyeball operations' and 'highly technical radiotherapy for oncological and non-oncological conditions'. The statutory definition is, thus, very vague, and, consequently, broad.

Mr Elchinov, instead of undergoing the removal of his eye, underwent highly advanced treatment in Germany, which helped his condition. Subsequently, he sought reimbursement of the cost of the German health treatment. The relevant court referred several questions to the Court of Justice. ${ }^{126}$

${ }_{124}$ Case 117/77 Bestuur van het Algemeen Ziekenfonds Drenthe-Platteland v G. Pierik [1978] ECR 825 para 22. This led to the changes enacted by Council Regulation (EEC) 2793/81 of 17 September 1981 amending Regulation (EEC) No 1408/71 on the application of social security schemes to employed persons and their families moving within the Community, and Regulation (EEC) 574/72 fixing the procedure for implementing Regulation (EEC) No $1408 / 71$. The latter inserted the rule that for the authorisation to be granted the treatment in question must be among the benefits provided for by the legislation of the Member State of residence.

${ }^{125}$ Case C-173/09 Georgi Ivanov Elchinov v National Health Insurance Fund (pending).

${ }^{126}$ Reference for a preliminary ruling from the Administrativen sad Sofia - grad (Bulgaria) lodged on 14 May 2009 - Georgi Ivanov Elchinov v National Health Insurance Fund (Case C-173/09). 
The essential issue is whether social security systems are obliged to cover foreign medical treatments which are not offered by domestic health care systems. On one side, there is the principle that EU law does not require Member States to extend the range of medical services they cover. ${ }^{127}$ On the other side, there is EFTA Court jurisprudence, according to which (EEA) Member States cannot prioritise their own, less effective treatments. ${ }^{128}$

The question, of course, is whether the term 'medical services' means 'health treatments' or 'medical conditions'. If the competent state defines covered health care by referring to medical conditions (diagnosis), does this mean that the state in question must not prioritise its own treatments for those conditions, against foreign, more advanced ones? If so, the competent state would have to cover the most advanced treatment for a certain diagnosis provided anywhere in the EU.

What if the competent state defines covered health care by referring to specified, enumerated treatments? Would those provisions be contrary to EU law if they included, in effect, only the treatments provided by domestic providers? It seems that the EFTA Court, when ruling that states are free to exclude certain treatments from their coverage, ${ }^{129}$ really means that they are free to exclude certain medical conditions (diagnoses). It remains to be seen whether the same logic applies to enumerated treatments.

What if the competent state defines social health coverage by referring to the type of treatment in a very general way, as in the Bulgarian case? Should the Bulgarian rules be interpreted as meaning the most advanced oncological treatment available within the EU'?

If the Court obliges Member States to cover more effective foreign treatments, the question of tariffs will also become significant. Application of the rules of the state of treatment (under the co-ordination system) can have serious financial consequences for Member States with less advanced domestic treatments. Should the possible justifications for limiting coverage of foreign treatment be redefined, in line with the principle of covering the most effective treatment? In other words, should specific criteria apply to the Member States with less technical and financial health resources, since they will probably be most affected by the outflow of patients to the Member States providing the most advanced (and, presumably, the most expensive) treatments. Let us hope the Court of Justice provides guidance in these matters.

\footnotetext{
127 Geraets-Smits (n 121) para 87.

128 Rindal (n 109) para 83.

129 Rindal (n 109) para 82.
} 


\section{Draft directive on patients' rights}

\section{Overview and problems}

The analysed case law has resulted in initiatives to resolve the issues raised by regulating patient mobility at the EU level by way of secondary legislation. This is a desirable development, taking into account the existing ambiguities as well as the political and social importance of the social security coverage of health care in Europe. However, it was not hard to predict that, due to the great diversity of social systems and living standards in the EU, it would not be easy to reach agreement on this matter. This is why the Commission proposal of 2008 (hereinafter: Original Proposal), ${ }^{130}$ despite several changes introduced during the legislative process, has, so far, not been adopted by the Council. Analysis here is focused mainly on the last available version (hereinafter: Directive Proposal), ${ }^{131}$ accompanied by a description of some differences with respect to the Original Proposal.

The Directive Proposal is based on TFEU art 114 (former EC Treaty art 95) on the approximation of Member States' laws for the establishment and functioning of the internal market, prescribing the ordinary legislative procedure (co-decision) for adoption. The other legal basis is TFEU art 168(5) (incentive measures) concerning Directive Proposal art 13 on European reference networks and art 15 regarding co-operation on health technology assessment. The choice of the legal basis is not surprising, since it is in line with the Court of Justice position that the social security coverage of health treatment obtained outside the Member State in which the patient is socially insured falls under the ambit of internal market rules. The main emphasis of the Directive Proposal is precisely the described situation.

The Directive Proposal offers certain solutions regarding the issue of social security related to patient mobility. It contains compromises to satisfy the EU Member States. However, several Member States (inter alia Spain) have opposed the proposed solutions. ${ }^{132}$ An important reason for their opposition is the definition of Member State of affiliation (the state covering the foreign treatment).

\footnotetext{
${ }^{130}$ Commission (EC), 'Proposal for a Directive of the European Parliament and of the Council on the application of patients' rights in cross-border health care' COM (2008) 414 final, 02 July 2008 (hereinafter: Original Proposal).

${ }^{131}$ Council (EU), 'Proposal for a Directive of the European Parliament and of the Council on the application of patients' rights in cross-border health care' annexed to the Committee of Permanent Representatives' note to the Council Interinstitutional File 2008/0142 (COD) 16005/09, 26 November 2009, retrieved from: http://www.epha.org/a/2878 (hereinafter: Directive Proposal).

${ }^{132}$ M Slegers, 'Ministers Stall on Cross-Border Health-Care' Europolitics (Brussels 2 December 2009) 9:
} 
The Directive Proposal provides that the Member State of affiliation is the one that is competent to grant prior authorisation under the coordination rules. ${ }^{133}$ The problem here is that, according to Regulation $883 / 2004$, the cost of authorised health care obtained by a pensioner outside his / her state of residence is covered by the institution of the state of residence if the latter state has opted for reimbursement on the basis of fixed amounts. ${ }^{134}$ The Member State of residence grants authorisation in the described situation. ${ }^{135}$ Therefore, it is hard to predict when the Patients Rights' Directive is to become adopted as part of the relevant legal framework.

Even when it is actually adopted, the directive will leave important issues unresolved. For instance, it does not reflect the new development in the jurisprudence arising from Rindal. ${ }^{136}$ The distinction between the medical conditions and medical treatments is not mentioned in the Directive Proposal. Therefore, the question of the real scope of Member States' freedom to define the social coverage of health care is left unanswered.

The Directive Proposal does not solve the problem of the parallel existence of two different systems of social security coverage of foreign health treatments: one based on the co-ordination rules and the other based on the Court of Justice case law and the proposed directive itself. Since those systems contain important disparities, the choice of method is essential, both for the patients and the national social security systems. Of course, the current situation, which the Directive Proposal does not solve, is detrimental to legal certainty and discourages patients from free movement and receiving health treatment abroad.

One of the ambiguous areas in the relationship between the co-ordination rules and the Directive Proposal concerns the level of coverage. The Directive Proposal, in art 8(3), prescribes that the amount of social security reimbursement for foreign health treatment shall not exceed the actual cost of the health care received. This may be contrary to Vanbrae$k e l$, which entitles the patient to receive the reimbursement based on the competent state's higher tariff instead of the state of treatment's (effecti-

\footnotetext{
133 Directive Proposal (n 131) art 4.

${ }^{134}$ Regulation (EC) 883/2004 of the European Parliament and of the Council of 29 April 2004 on the coordination of social security systems [2004] OJ L166/1 (hereinafter: Regulation 883/2004) art 27(5). Not surprisingly, Spain is one of those states (and is hosting many pensioners from the northern Member States of the EU). See to that effect Regulation (EC) $987 / 2009$ of the European Parliament and of the Council of 16 September 2009 laying down the procedure for implementing Regulation (EC) 883/2004 on the coordination of social security systems [2009] OJ L284/1 (hereinafter: Regulation 987/2009) Annex 3.

135 Regulation 883/2004 art 27(5).

136 Joined Cases E-11/07 and E-1/08 Olga Rindal and Therese Slinning $v$ The Norwegian State [2008] EFTA Ct Rep 319.
} 
vely paid) lower tariff. ${ }^{137}$ Since the Court of Justice has based Vanbraekel on the direct application of the highest source of EU law, ${ }^{138}$ its stance towards the newly proposed solution is not easy to predict.

On the other hand, the Directive Proposal seems to be in line with Watts. ${ }^{139}$ Does this mean that the principle stated in the latter case, of imposing the amount of the actual costs as the limit of reimbursement, also applies to cases where the competent state's level of coverage (percentage of the cost of the treatment) is not higher than the coverage in the state of treatment, but where the overall reimbursement is, due to the higher costs in the competent state? Answers to these questions are awaited. ${ }^{140}$

Furthermore, the requirements for granting authorisation under the Directive Proposal impose additional restrictions on the patient wishing to travel abroad to obtain health treatment. The Directive Proposal, in article 9 (3a), allows the patient to choose either the co-ordination system, or the Directive Proposal System. Next, it states that authorisation may be refused (in addition to other, non-specified reasons in the general interest) if:

1. The patient is not entitled to the treatment in question.

2. The treatment can be provided in the Member State of affiliation within a time-limit which is medically justifiable, taking into account the current state of health and the probable course of the illness of the person concerned.

3. The patient, according to a clinical evaluation with reasonable certainty, will be exposed to a patient safety risk that cannot be considered to be normal, taking into account the potential benefit for the patient of the sought cross-border health care.

4. The general public, with reasonable certainty, will be exposed to a substantial safety hazard as a result of the cross-border health care in question. ${ }^{141}$

Therefore, the Directive Proposal opens the door for additional grounds for justification when compared to the co-ordination rules and the previous case law. However, the Original Proposal, in arts 3 and 9, was even more radical in that respect. It completely separated the criteria for defining 'undue delay' or 'medically justifiable time' from the criteria for granting authorisation under the co-ordination rules. ${ }^{142}$ Furthermore, it

${ }^{137}$ Case C-368/98 Abdon Vanbraekel and Others $v$ Alliance nationale des mutualités chrétiennes (ANMC) [2001] ECR I-5363 para 53.

138 Vanbraekel (n 137) para 53.

${ }^{139}$ Case C-372/04 The Queen on the application of Yvonne Watts $v$ Bedford Primary Care Trust Secretary of State for Health [2006] ECR I-4325, para 131.

140 An equivalent provision has also been inserted into Regulation 987/2009 art 26(7).

${ }^{141}$ Directive Proposal (n 131) art 9(5).

${ }^{142}$ Original Proposal (n 130) art 3(2). 
did not leave the possibility for the patient to choose the applicable regime (if the conditions for applying the co-ordination rules were met, those rules were to become applicable). ${ }^{143}$ The question now remains whether the Court will interpret the directive (if, eventually, it is adopted) in a literal way, or more in line with the previous case law.

The definition of care which may be subject to prior authorisation, and its relationship with the Court of Justice distinction between hospital and non-hospital treatments, is also ambiguous. It includes, apart from overnight stays in hospitals, for instance, health care which requires planning because it involves the 'use of highly specialized and costintensive medical infrastructure or medical equipment'. ${ }^{144}$ This definition can be interpreted broadly, in fact, more broadly than the Court's notion of hospital treatment (which is, in itself, vague).

Furthermore, it is important to note that the Directive Proposal does not define 'international medical standards'. Therefore, the questions of which international documents can be used, and how broadly the term should be defined, remain unanswered.

An important addition to the case law lies in the part of the Directive Proposal dealing with national contact points for cross-border health care. These should be set up in every Member State (both for outgoing and incoming patients) and should provide patients with all the relevant information. ${ }^{145}$

Finally, it is important to note that the Directive Proposal contains an obligation imposed on the Member State of treatment not to discriminate against incoming patients from other Member States. ${ }^{146}$ However, the Member State of treatment can impose restrictions justified by overriding reasons of general interest. ${ }^{147}$ The rationale of these restrictions is to prevent an increase in waiting times, due to potentially large numbers of patients coming from other Member States to obtain treatment. ${ }^{148}$

\section{Impact on new Member States and Croatia}

The first problem new Member States have to tackle has already become visible. ${ }^{149}$ As was observed in the literature, it is hard for new Mem-

\footnotetext{
${ }^{143}$ Wolf Sauter, 'The Proposed Patients' Rights Directive and the Reform of (Cross-Border) Healthcare in the European Union' (2009) 36 Legal Issues of Economic Integration 109, 119.

144 Directive Proposal (n 131) art 9(2).

145 Directive Proposal (n 131) art 7.

146 Directive Proposal (n 131) art 5(3).

147 Directive Proposal (n 131) art 5(3).

148 Preamble to the Directive Proposal (n 131) para 12(a).

149 Case C-173/09 Georgi Ivanov Elchinov v National Health Insurance Fund (pending).
} 
ber States to adopt all the newest technologies for providing health care treatments. ${ }^{150}$ This is caused, inter alia, by the generally much lower per capita expenditure on health care in the new Member States compared to the old Member States. ${ }^{151}$ Therefore, the new Member States are the ones most likely to find themselves in the situation where more advanced health treatments are available abroad. The adoption by the Court of Justice of the patient's freedom to receive socially covered foreign treatment, more advanced than domestic treatment (already stipulated by the EFTA Court), could thus lead to a significant outflow of patients towards western, more developed, Member States.

It seems that the most important factor influencing the Member States' obligations to socially cover foreign health treatments will be the way the rules on social security coverage are phrased. In this context, statutory rules like the Croatian ones, according to which the complete cure of malignant diseases will be paid in full by the Croatian Health Insurance Institute (read together with broad statutory definitions of socially covered types of health care), ${ }^{152}$ translated into EFTA Court language and applied within the EU context, may be understood to include 'the most effective cure of malignant diseases available anywhere within the EU'.

Therefore, if the right to social coverage of more effective foreign treatment is accepted by the Court of Justice, a Member State wanting to limit the scope of health care its social system covers needs to define that coverage more precisely, by using objective, non-discriminatory criteria. ${ }^{153}$ On the other hand, it becomes questionable whether a precise, detailed list of included (or excluded) treatments would in itself be contrary to the internal market, if a Member State is unable to justify why certain precise treatments are, for example, excluded (apart from the reason that they are not provided by the domestic health system due to a lack of resources). Another problem is that the EFTA Court equates treatments and conditions (diagnosis) when it states that the Member States are free

\footnotetext{
${ }^{150}$ Alina Kaczorowska, 'A Review of the Creation by the European Court of Justice of the Right to Effective and Speedy Medical Treatment and its Outcomes' (2006) 12 European Law Journal 345, 367; AP den Exter 'Legal Consequences of EU Accession for Central and Eastern European Health Care Systems' (2002) 8 European Law Journal 556, 562.

${ }^{151}$ WHO 'National Health Accounts' <http://www.who.int/nha/country/en/index.html> accessed on 20 May 2010.

${ }^{152}$ Compulsory Health Insurance Act (Official Gazette 150/08, 94/09, 153/09) art 16 (Zakon o obveznom zdravstvenom osiguranju NN 150/08, 94/09, 153/09, cl. 16.) author's translation. The Act also refers to the financial capacity of the Institute in art 15, which contains rather broad definitions of the types of health care the coverage of which the patients are entitled to.

${ }_{153}$ Joined Cases E-11/07 and E-1/08 Olga Rindal and Therese Slinning $v$ The Norwegian State [2008] EFTA Ct Rep 319, para 82.
} 
to define the treatments they cover. ${ }^{154}$ What happens, then, if the covered treatments for each disease are precisely defined by statutes? Can the Member States exclude treatments for the same disease which are more effective than those enumerated by law?

Nevertheless, it seems that, for the time being, the safest way for the Member States to limit their coverage is to use extensive lists of included (positive lists) or excluded (negative lists) treatments instead of broad definitions like 'normal treatments' or 'specialist care'. However, the trend seems to be to limit such Member State autonomy further, so the final outcome remains to be seen. In any case, in order to prevent the uncontrolled outflow of patients to Member States with the most advanced health care, which may seriously jeopardise the stability of their social security systems, new Member States need to study in detail the EU legal framework and adapt their own legislation where necessary.

The second important element the new Member States have to be aware of is the Court of Justice's interpretation of the co-ordination rules. As stated in Inizan, the Member States may not refuse to grant authorisation if an equally effective treatment cannot be provided in the state where the patient is resident without undue delay, taking into account his / her level of pain, medical history, and ability to carry out professional activity. ${ }^{155}$ The Court's reasoning thus significantly decreases the possibilities for Member States to reduce the outflow of patients abroad.

The latter development regarding the interpretation of the co-ordination rules can have significant consequences for the new Member States. The basis for this claim is the fact that, under the co-ordination rules, the competent state covers the costs of foreign health treatment according to the foreign (the state of treatment's) rules, and, thus, the foreign tariffs. The Slovak government suggested that health services in some Member States can be 5-10 times more expensive than in other Member States. ${ }^{156}$

It is also important to note that the Member State with the lowest GDP per capita in Purchasing Power Standards (PPS) of the old Member States in 2008 was Portugal, with $76.0 \%$ of the EU average, while Greece was second with $94.3 \%$ of the EU average. The new Member State with the highest GDP per capita in PPS in 2008 was Cyprus with 95.9\% of the EU average. Bulgaria had the lowest GDP per capita in PPS in 2008, with $41.3 \%$ of the EU average. ${ }^{157}$ If we take into account only the new Central

\footnotetext{
154 Rindal (n 153) para 82.

155 Case C-56/01 Patricia Inizan v Caisse primaire d'assurance maladie des Hauts-de-Seine [2003] ECR I-12403 para 46.

156 Commission (EC) 'Community Action on Health Services' (Summary report of the responses to the consultation) SEC (2006) 1195/4, 26 September 200612.

157 No data available for Romania.
} 
European Member States, the highest GDP per capita in PPS in 2008 was in Slovenia, with $90.9 \%$ of the EU average. In 2008, Croatia had a GDP per capita in PPS at the level of $62.7 \%$ of the EU average. ${ }^{158}$

Therefore, patients from new Member States are less likely to travel to old Member States under primary law rules (according to which they have to pay for the treatment on the spot and subsequently claim reimbursement) since coverage will be based on competent state tariffs. Moreover, the obligation to pay the provider on the spot can act as a strong disincentive for those patients.

However, under the co-ordination rules, coverage is settled between the two social insurers (so the patient, usually, does not have to pay the provider on the spot for the whole cost of treatment) and the applicable tariff is the state of treatment tariff. Of course, if, for example, Poland has to cover according to German tariffs the treatment of patients who travel to Germany in order to bypass Polish waiting lists, then that could cause financial problems for the Polish social security system.

These problems could result in a shift from using the severity of diagnosis as a criterion for determining the level of coverage (and the level of co-payment, the contribution of the patient in the cost of the treatment) towards using prices, thereby undermining solidarity within the social security system. ${ }^{159}$ In any case, it is not likely that EU law on patient mobility will reduce the direct contribution of patients in health care costs.

EU law on patient mobility can have some positive effects on the new Member States and Croatia. One positive aspect is that it may provide an incentive for more co-operation and practical co-ordination between the social security systems of the Member States and lead to an increase in efficiency. ${ }^{160}$

This increased co-operation may be used to alleviate problems of limited resources and waiting lists by developing policies of referring certain patients abroad in particular cases. A more advanced stage would be to 'divide work', in the sense that individual Central European Member States specialise in a different highly advanced treatment, so that the social systems can refer patients among themselves. This would be especially significant for smaller Member States which, due to the lack of funds and demand (because of the limited numbers of patients in need

\footnotetext{
158 According to EUROSTAT <http:/ / epp.eurostat.ec.europa.eu/tgm/table.do?tab=table\&i nit $=1 \&$ plugin $=1 \&$ language $=$ en\&pcode $=$ tsieb010 $>$ accessed on 20 May 2010 .

159 This means that the higher percentage of co-payments would be demanded from the patient for more expensive treatments of the most serious diseases.

${ }^{160}$ See Vassillis Hatzopoulos, 'A (more) Social Europe: A Political Crossroad or a Legal OneWay? Dialogues between Luxembourg and Lisbon' (2005) 42 CML Rev 1599, 1617.
} 
of certain treatments), cannot maintain feasible human and technical resources (involving high fixed costs) for conducting certain treatments.

\section{Proposed course of action}

Patients travelling to other Member States in order to obtain treatment are still a relatively rare phenomenon in the EU. The European Commission estimates that around $1 \%$ of total health-care spending relates to this area. ${ }^{161}$ However, a significant increase has been seen in the last few years, representing an upward trend. ${ }^{162}$ Therefore, the social significance of the topic is constantly rising, emphasising the need for more legal certainty at the European level.

It is first essential to unite the two existing systems of social security coverage of health care obtained abroad, preferably through a single legislative instrument, to avoid the existence of two parallel systems, one not clearly delineated from the other (thus confusing patients regarding the possibilities for them to obtain foreign treatment). There is no reason why this could not be done as part of the existing co-ordination rules. These rules have been in existence for decades and are familiar to the social security authorities. Another important aspect is that the co-ordination rules are based on directly applicable regulations, which are thus a more effective tool for maintaining a coherent policy, at the European level, than directives, which need to be transposed into Member States' legislation.

The co-ordination rules should, therefore, incorporate the case law on the right to receive more advantageous reimbursement from the competent state. ${ }^{163}$ It should be made clear that, in every situation, two calculations are made. One calculation is based on the costs and coverage of the equivalent (to the obtained) treatment in the competent state, and the other on the costs and coverage within the state of treatment. It should also be made clear that a limit is set at the level of the actual cost of the treatment. It is, however, necessary for the Court of Justice to clarify its position to avoid the risk of secondary legislation being contrary to the Court's interpretation of primary law. Without the Court's clarification, the only way is to literally transcribe the Court of Justice's statements on the topic.

\footnotetext{
${ }^{161}$ Commission (EC), 'Community action on health services' (Summary report of the responses to the consultation) SEC (2006) 1195/4, 26 September 20067.

${ }^{162}$ Summary report (n 161) 8.

${ }^{163}$ Already present, to a certain extent, in Regulation (EC) 987/2009 of the European Parliament and of the Council of 16 September 2009 laying down the procedure for implementing Regulation (EC) 883/2004 on the coordination of social security systems [2009] OJ L284/ 1 art 26(7).
} 
Second, it is imperative to resolve the problems of legal uncertainty in defining conditions and treatments which are to be covered by national social security packages. It is especially important to determine the relationship between the national social security system's right to define the socially covered medical conditions and its obligation to cover foreign more effective treatments which are different from those offered by the domestic health system. Of course, it is necessary first to hear the Court of Justice stance on the matter (whether it will use the same logic as the EFTA Court), which will probably occur in the coming Elchinov judgement. ${ }^{164}$

To protect the stability of social security systems, especially those less technically modern and not financially strong, it is essential to give, by means of EU legislation, freedom to Member States to clearly define treatments which will not be covered, even if they are more effective than the treatments available on their own territory. This approach would further strengthen the Member States' freedom to define their social packages, by ruling out the possibility of positive and negative lists of socially covered treatments being contrary to the internal market, because of indirectly discriminating cross-border patients. ${ }^{165}$

If Member States are not allowed to exclude from their social packages certain treatments, while including other treatments for the same diagnosis, Member States might opt to entirely exclude certain diagnoses from coverage (in order not to be accused of giving preference to domestic health treatments over foreign ones). In the end, these developments could have a detrimental effect on patient mobility. In order to deal directly with the division of competence between the EU and Member States, the use of (binding) legislation seems necessary.

Third, a need exists to legally define international medical standards, since they are used by the Court of Justice as a benchmark for assessing the social security systems' obligation to cover foreign health treatments. The critical questions here are: Which standards are relevant? Which international documents should be used? Should we be limited only to Europe, or should we try to find a global common standard? ${ }^{166}$ What about situations where there is no consensus of the scientific commu-

${ }^{164}$ Case C-173/09 Georgi Ivanov Elchinov v National Health Insurance Fund (pending).

165 The EFTA Court stated that EEA States may decide that certain treatments are not offered domestically if the criteria for the exclusion are objective and non-discriminatory. See Joined Cases E-11/07 and E-1/08 Olga Rindal and Therese Slinning $v$ The Norwegian State [2008] EFTA Ct Rep 319 para 82. The question is, however, if the specified lists of covered treatments (not conditions) can be seen as indirectly discriminating providers who provide different treatments for the same diagnosis.

${ }^{166}$ A question raised by TK Hervey and JV McHale, Health Law and the European Union (Law in Context Series, CUP, Cambridge 2004) 137. 
nity? Which part of the scientific community should be taken into account? Which methods of control and verification should be used?

In this regard, it is important to investigate the legal possibilities and instruments to define those standards, namely whether to use binding or non-binding instruments. Again, taking into account the diversity of social security systems and how politically sensitive the issue is, a bottoms-up approach of non-binding co-operation between the national social security systems (with guidance from the Commission) seems the best course of action.

The EU should organise further wide consultation to receive feedback from all the interested parties and then bring them together to determine points of agreement and disagreement. This approach would also be in the best interest of the social security authorities, because it would give them the chance to actively take part in the process of something many of them could call 'damage control'. In any case, legislative pressure from the EU might cause dissatisfaction from the Member States, which can be seen regarding the Directive Proposal.

Fourth, since waiting lists are one of the strongest incentives for the cross-border movement of patients, ${ }^{167} \mathrm{EU}$ action in the area is needed. One possibility is to set up a system of European waiting lists which would be used to fix imbalances which might arise from significant outflows of patients from certain Member States. Developing European centres of quality for specific health treatments and dispersing them within the EU is another way to find a balance between different social security systems and regions within the Union. Again, the choice of legal instruments and methods needs to be investigated in detail. The main impetus should again be provided by the social security bodies, which are best equipped in terms of expertise to deal with this issue.

It is also important to note that, even with the adoption of the Patients' Rights Directive, significant room will remain for Member States to address issues of cross-border health care independently. This is especially the case in the area of defining health conditions and treatments which are covered by social security packages, and also criteria for defining those packages (how to enumerate the covered treatments, whether to use treatments or conditions as benchmarks, and so on).

The cost containment policies of the Member States will be affected by the free movement of patients. It is thus important for the Member States to investigate the best ways to define their social coverage, in terms of maintaining the solidarity of social security systems. Another question

${ }_{167}$ Visible in Case C-372/04 The Queen on the Application of Yvonne Watts $v$ Bedford Primary Care Trust Secretary of State for Health [2006] ECR I-4325 para 90. 
is whether a need will arise for states to shift away from the severity of the treated condition towards the price of treatment as the crucial factor in determining the amount (percentage) of basic social security coverage of a given procedure. Therefore, intensified dialogue between the EU and the Member States is needed.

\section{Conclusion}

EU law on patient mobility has evolved over the course of the last 12 years. Unfortunately, all the issues raised have not yet been solved. Furthermore, new questions have arisen from the recent EFTA Court case law, which does not contribute to an increase of legal certainty at the EU level.

This legal certainty can be achieved by two types of measures: binding legislation and co-operation among national social security systems. Binding rules are needed in areas which directly delineate the division of competence between the EU and the Member States (the freedom of Member States to define the packages of covered health treatments). These legislative measures should maintain the freedom of Member States to define their social packages, even if this means excluding certain more advanced foreign treatments from coverage.

Maintaining the mentioned freedom is necessary to protect the financial stability of social health care systems in less developed Member States, preserving access to health care of less well-off patients (and thus solidarity). Limiting the Member States' freedom to define their social security packages may, on the other hand, lead to exclusion from coverage of certain diagnoses, which would be detrimental to patient cross-border mobility.

In more technical areas, such as defining hospital and non-hospital treatment and international medical standards, the expertise and experience of social security institutions speak in favour of a more bottoms-up approach. However, if legislative EU action is used in the latter areas, it should be subjected to the maximum level of democratic participation and public scrutiny, due to the politically and socially sensitive nature of the issue.

Finally, national social security officials and policy makers should become acquainted with the legal developments at the EU level. An indepth knowledge of EU law on patient mobility is necessary in order for the national systems to formulate their regulations in a manner which respects the EU legal framework, while protecting the basic social objective, the solidarity of the national systems. 